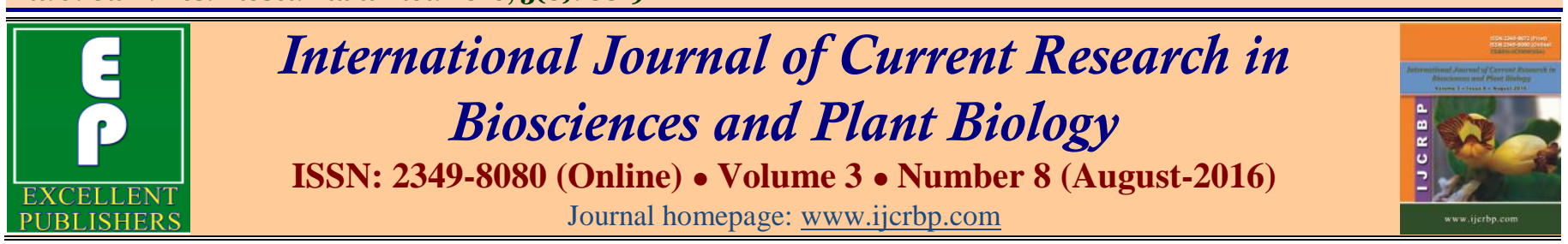

\title{
Impact of Seaweed Liquid Fertilizers on Productivity of Blackgram [Vigna mungo (L.) Hepper]
}

\author{
A. Subbarami Reddy ${ }^{*}$, P. Venkata Rao $^{2}$, J. Sateesh Babu ${ }^{3}$ and M. V. Ramana4 \\ ${ }^{1}$ Scientist (Agronomy), Regional Agricultural Research Station (RARS), Lam-522 034, Guntur, Andhra Pradesh, India \\ ${ }^{2}$ Senior Scientist (Agronomy), Regional Agricultural Research Station (RARS), Lam-522 O34, Guntur, Andhra Pradesh, India \\ ${ }_{3}^{3}$ Scientist (Plant Breeding), Regional Agricultural Research Station (RARS), Lam-522 O34, Guntur, Andhra Pradesh, India \\ 4Principal Scientist (Pulses), Regional Agricultural Research Station (RARS), Lam-522 o34, Guntur, Andhra Pradesh, India
}

*Corresponding author.

\begin{abstract}
A bstract
A field experiment was conducted at Regional Agricultural Research Station, Lam, Guntur during kharif seasons of 2012 and 2013 to study the effect of seaweed liquid fertilizers on growth and yield of blackgram on deep black clay loam soils. The seaweed extracts, viz., Kappaphycus alvarezii and Gracilaria edulis were applied to the foliage twice at diverse concentrations $(0,2.5,5.0,7.5,10.0$ and $15.0 \% \mathrm{v} / \mathrm{v})$ during crop growth period. Control plot was sprayed with water. Foliar application of either Kappaphycus and Gracilaria at flowering stage and pod development stage resulted in significant increase in plant height, branches per plant, number of pods per plant, test weight (100 grain) and grain yield over the control. It was found that both the extracts were very effective and enhanced the growth and yield. The seed yield had increased by $60.8 \%$ and 50.8\% with foliar application of Kappaphycus sap and Gracilaria sap, respectively when applied at $10 \%$ concentration over the control (water spray).
\end{abstract}

\section{Article Info}

Accepted: 17 July 2016

Available Online: 06 August 2016

Keywords

Blackgram

Gracilaria edulis

Kappaphycus alvarezii

Liquid fertilizers

Seaweeds

\section{Introduction}

The use of seaweeds as manure in farming practices is very ancient and common practice among the Romans and also practiced in Britain, France, Spain, Japan and China. Organic fertilizers have contributed for deposition of crop residues, physical and chemical properties of soil (Galbiattia et al., 2007). Among the organic sources as supplemental fertilizers, seaweed extract have been used (Zodape, 2001). Marine bioactive substances extracted from marine algae are used in agricultural and horticultural crops, and many beneficial effects may be achieved in terms of enhancement of yield and quality. Liquid extracts obtained from seaweeds have recently gained importance as foliar sprays for many crops including various cereals, pulses and different vegetable species. Seaweed extracts contain major and minor nutrients, amino acids, vitamins, cytokinins, auxins and abscisic acid and have been reported to stimulate the growth and yield of plants, develop tolerance to environmental stress (Zhang et al., 2003), increase nutrient uptake from soil (Turan and Kose, 2004) and enhance antioxidant properties (Verkleij, 1992). Seaweed liquid fertilizers treatment increased the number of branches and concentration of photosynthetic pigments (Sridhar and Rengasamy, 2010) in okra. The extracts derived from seaweeds are biodegradable, non-toxic, non-polluting and non-hazardous to humans, animals and birds (Dhargalkar and Pereira, 2005).

India is the largest producer and consumer of pulses in the world contributing around $25-28 \%$ of the global production. Among the grain legumes, blackgram is the most important legume crop grown and consumed in 
India and is a good source of carbohydrates, proteins and minerals. Therefore, the present study was conducted to evaluate the efficacy of different concentrations of seaweed extracts (Kappaphycus alvarezii and Gracilaria edulis) in improving the growth and yield of blackgram [Vigna mungo (L.) Hepper] grown in field under rainfed condition.

\section{Materials and methods}

A field experiment was conducted for two years from 2012-2013 during kharif seasons at Regional Agricultural Research Station, Lam, Guntur to find out the effect of seaweed liquid fertilizers on productivity of blackgram. The soil of the experimental site was clay loam in texture with soil $\mathrm{pH}$ was neutral in reaction (6.8) and an electrical conductivity of $0.45 \mathrm{dSm}^{-1}$. The soil organic carbon content was low $(0.61 \%)$. The soil was low in available nitrogen (203 kg ha $\left.{ }^{-1}\right)$, medium in available phosphorus (22.4 $\left.\mathrm{kg} \mathrm{ha}^{-1}\right)$ and available potassium $\left(412 \mathrm{~kg} \mathrm{ha}^{-1}\right)$.
The experiment comprised of ten treatments and the details of the treatments are mentioned Table 1. Two sprays of Kappaphycus alvarezii and Gracilaria edulis extracts were given; one at the flowering stage and the other at the pod development stage. These seaweed extracts were collected from Central Salt and Marine Chemicals Research Institution (Council of Scientific and Industrial Research), Bhabnagar, Gujarat. For proper adherence, the extracts were mixed with proper surfactant (active 80 at $0.5 \mathrm{ml} \mathrm{l}^{-1}$ of water) at the time of spraying. The total spray volume was $5001 \mathrm{ha}^{-1}$ in each application. The treatments were distributed in a randomized block design with three replications. The plot size was $5 \times 6 \mathrm{~m}$. The recommended dose of fertilizer (RDF) for blackgram was 20-50-0 kg N, $\mathrm{P}_{2} \mathrm{O}_{5}$ and $\mathrm{K}_{2} \mathrm{O}$ ha $^{-1}$, respectively and all fertilizers were applied as basal through Urea and Single Super Phosphate (SSP). Date of sowing was $13^{\text {th }}$ and $15^{\text {th }}$ of July, 2012 and 2013 and the crop was harvested on $1^{\text {st }}$ and $5^{\text {th }}$ October, 2012 and 2013, respectively. The crop was grown with standard packages of practices for the region.

Table 1. Details of experimental treatments.

\begin{tabular}{lll}
\hline Treatment & Details & Time of application \\
\hline $\mathrm{T}_{1}$ & $2.5 \%$ Kappaphycus sap spray & Flower initiation and pod formation \\
$\mathrm{T}_{2}$ & $5.0 \%$ Kappaphycus sap spray & Flower initiation and pod formation \\
$\mathrm{T}_{3}$ & $10 \%$ Kappaphycus sap spray & Flower initiation and pod formation \\
$\mathrm{T}_{4}$ & $15 \%$ Kappaphycus sap spray & Flower initiation and pod formation \\
$\mathrm{T}_{5}$ & $2.5 \%$ Gracilaria spray & Flower initiation and pod formation \\
$\mathrm{T}_{6}$ & $5.0 \%$ Gracilaria spray & Flower initiation and pod formation \\
$\mathrm{T}_{7}$ & $10 \%$ Gracilaria spray & Flower initiation and pod formation \\
$\mathrm{T}_{8}$ & $15 \%$ Gracilaria spray & Flower initiation and pod formation \\
$\mathrm{T}_{9}$ & Water spray & Flower initiation and pod formation \\
$\mathrm{T}_{10}$ & $7.5 \%$ Kappaphycus spray & Flower initiation and pod formation \\
\hline
\end{tabular}

Plant height at harvest was recorded for randomly selected five plants. Data on yield components viz., branches plant ${ }^{-1}$, pods plant ${ }^{-1}$ and test weight (100 grains) was also recorded.

\section{Results and discussion}

\section{Growth}

Plant height was recorded at harvesting stage and the data presented in Table 2. The plant height increased up to 10 $\%$ concentration of both seaweed extracts. The maximum plant height was recorded with $10 \%$ of Gracilaria sap $(53.7 \mathrm{~cm})$ in $1^{\text {st }}$ year, however, in $2^{\text {nd }}$ year with $7.5 \%$ of Kappaphycus sap $(47.4 \mathrm{~cm})$ and both values were significantly superior over control $(33.3 \mathrm{~cm}$ and $41.8 \mathrm{~cm}$, respectively in 2012 and 2013). The increase in plant height with seaweed liquid fertilizer may be due to its stimulation effect on growth and development resulting in good health of plants, while deliberating the effect of seaweed liquid fertilizer on crops the aspects of root development and mineral absorption, shoot growth and photosynthesis of the plant system. These findings are in agreement with those of Pramanick et al. (2013), Gurusaravanan et al. (2011) and Zodape et al. (2010).

The maximum number of branches per plant and pods per plant was recorded with foliar application of Kappaphycus or Gracilaria sap with $10 \%$ concentration and further increase in concentration reduction was noticed in both parameters. The maximum number of branches per plant (3.2) was recorded with Kappaphycus @ 7.5\% and this is statistically at par with $10 \%$ concentration of both seaweed extracts. 
Table 2. Effect of seaweed liquid fertilizer on growth and yield of Blackgram during 2012 and 2013 at RARS, Lam.

\begin{tabular}{|c|c|c|c|c|c|c|c|c|c|c|c|c|c|c|c|}
\hline \multirow{2}{*}{ Treatments } & \multicolumn{3}{|c|}{ Plant height (cm) } & \multicolumn{3}{|c|}{ No. of branches/plant } & \multicolumn{3}{|c|}{ No. pods/plant } & \multicolumn{3}{|c|}{100 seed weight $(g)$} & \multicolumn{3}{|c|}{ Seed Yield (kg/ha) } \\
\hline & 2012 & 2013 & Mean & 2012 & 2013 & Mean & 2012 & 2013 & Mean & 2012 & 2013 & Mean & 2012 & 2013 & Mean \\
\hline $\mathbf{T}_{1}$ & 40.0 & 45.3 & 42.7 & 1.7 & 2.6 & 2.2 & 35.0 & 39.2 & 37.1 & 3.7 & 5.2 & 4.5 & 823 & 658 & 741 \\
\hline $\mathbf{T}_{2}$ & 43.7 & 44.3 & 44.0 & 1.9 & 2.6 & 2.3 & 36.3 & 38.5 & 37.4 & 3.7 & 5.1 & 4.4 & 863 & 692 & 778 \\
\hline $\mathbf{T}_{3}$ & 40.7 & 46.2 & 43.5 & 2.1 & 3.0 & 2.6 & 47.7 & 46.1 & 46.9 & 3.9 & 5.4 & 4.7 & 1043 & 950 & 997 \\
\hline $\mathbf{T}_{4}$ & 37.7 & 47.2 & 42.5 & 2.0 & 2.9 & 2.5 & 37.0 & 39.3 & 38.2 & 3.7 & 4.8 & 4.3 & 735 & 817 & 776 \\
\hline $\mathbf{T}_{5}$ & 39.7 & 45.6 & 42.7 & 2.5 & 2.6 & 2.6 & 35.0 & 39.4 & 37.2 & 3.8 & 4.8 & 4.3 & 650 & 563 & 607 \\
\hline $\mathbf{T}_{6}$ & 50.7 & 46.1 & 48.4 & 2.5 & 2.9 & 2.7 & 36.0 & 36.4 & 36.2 & 3.7 & 5.3 & 4.5 & 800 & 817 & 809 \\
\hline $\mathbf{T}_{7}$ & 53.7 & 45.1 & 49.5 & 2.2 & 3.0 & 2.6 & 42.0 & 41.9 & 42.2 & 3.8 & 4.7 & 4.3 & 993 & 876 & 935 \\
\hline $\mathbf{T}_{8}$ & 39.7 & 46.1 & 42.9 & 2.2 & 2.9 & 2.6 & 38.0 & 41.5 & 39.8 & 3.7 & 5.2 & 4.5 & 780 & 750 & 765 \\
\hline $\mathbf{T}_{9}$ & 33.3 & 41.8 & 37.6 & 2.0 & 2.5 & 2.3 & 35.3 & 33.5 & 34.4 & 3.7 & 4.7 & 4.2 & 615 & 625 & 620 \\
\hline $\mathbf{T}_{10}$ & 46.7 & 47.4 & 47.1 & 1.4 & 3.2 & 2.3 & 44.3 & 42.9 & 43.6 & 3.7 & 5.1 & 4.4 & 985 & 883 & 934 \\
\hline SEM \pm & 1.9 & 1.0 & & 0.3 & 0.13 & & 2.2 & 1.477 & & 0.1 & 0.2 & & 30 & 38.52 & \\
\hline $\mathrm{CD}(p=0.05)$ & 5.6 & 3.0 & & N.S & 0.4 & & 6.5 & 4.39 & & N.S & 0.5 & & 88 & 114 & \\
\hline
\end{tabular}

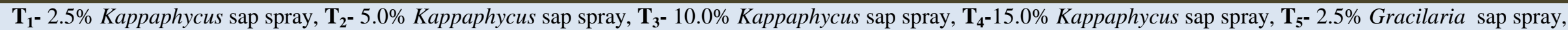
$\mathbf{T}_{\mathbf{6}}-5.0 \%$ Gracilaria sap spray, $\mathbf{T}_{\mathbf{7}}-10.0 \%$ Gracilaria sap spray, $\mathbf{T}_{\mathbf{8}} \mathbf{- 1 5 . 0 \%}$ Gracilaria sap spray, $\mathbf{T}_{\mathbf{9}}$ - Water spray, $\mathbf{T}_{\mathbf{1 0}} \mathbf{- 1 . 5 \%}$ Kappaphycus sap spray. 
The present study clearly indicated that application of seaweed extracts is beneficial to enhance overall growth of blackgram as compared to control plants. Increase in plant height and number of branches per plant have been reported in different crops by seaweed extract application (Ayun et al., 2008; Kumar and Sahoo, 2011; Dwivedi et al., 2014 and Ganesh et al., 2015).

\section{Yield attributes}

The effect of seaweed extracts on yield attributes and yield is presented in Table 2. An increase in yield attributes such as number of pods per plant and test weight were found to be increased up to $10 \%$ of both seaweed extracts and then declined at higher concentration (Table 2). But these two are statistically on a par with Kappaphycus sap spray $7.5 \%$ concentration. The highest test weight was observed with $10 \%$ foliar spray of Kappaphycus sap $(5.4 \mathrm{~g})$ followed by $5 \%$ of Gracilaria sap (5.3 g) in 2013, however, both are at par with each other but, significantly superior over control $(4.7 \mathrm{~g})$. The increased yield attributes may be due to the presence of some growth promoting substances such as IAA and IBA, gibberellins, cytokinins, micronutrients, aminoacids. This is in conformity with the findings reported for Capsicum annum (Arthur et al., 2003); blackgram (Dwivedi et al., 2014 and Ganesh et al., 2015); canola plants (Ferreira and Lourens, 2002); greengram (Zodape et al., 2010 and Venkata Rao et al., 2015) and potato (Dwivedi et al., 2014).

\section{Yield}

Significant increase in grain yield was recorded up to 10 $\%$ concentration of Kappaphycus or Gracilaria sap and then declined at higher concentration. Foliar application of seaweed liquid fertilizers (10\%) resulted in higher grain yields over control to the extent of $60.8 \%$ (Kappaphycus) and 50.8\% (Gracilaria) which was the highest and superior when compared to control plot (water spray). The increase in grain yield was mainly due to increase in number of branches per plant, as well as number of pods per plant and test weight. The beneficial effects of seaweed extract may be due to presence of some growth promoting substances (IAA, IBA, Gibberelins, Cytokinins, micronutrients, vitamins and aminoacids). Our results are in close conformity with those findings previously reported by Pranamick et al. (2013), Bai et al. (2008), Zodape et al. (2008) and Gurusaravanan et al. (2011). The yields of several crops like greengram (Venkata Rao et al., 2015), Capsicum annum (Arthur et al., 2003), canola plants (Ferreira and
Lourens, 2002), Abelmoschus esculentus (Thirumaran et al., 2009) and potato (Dwivedi et al., 2014) have increased with foliar application of seaweed extracts.

\section{Conclusion}

In this study, experimental evidence does indicate that seaweed liquid fertilizers are very effective and enhanced grain yield of blackgram. The grain yield of blackgram was increased by $60.8 \%$ and $50.8 \%$ with foliar application of Kappaphycus and Gracilaria extracts, respectively at $10 \%$ concentration in comparison to control treatment. This may be due to the stimulation effect of growth promoting substances such as IAA, IBA, gibberellins, cytokinins, vitamins, aminoacids and micronutrients. It may be concluded that liquid seaweed extracts could serve as cost effective eco-friendly product for sustainable agriculture, but their level should be appropriate to enhance growth and productivity.

\section{Conflict of interest statement}

Authors declare that they have no conflict of interest.

\section{References}

Arthur, G.D., Stirk, W. A., Van Staden, J., 2003. Effect of seaweed concentrates on the growth and yield of three varieties of Capsicum annuum. S. Afr. J. Bot. 69, 207211.

Ayun Vinuba, Pinky, V. R., Praksah, J. W., 2008. Effect of seaweed extract on growth and biochemical parameters of blackgram. Plant Arch. 8(1), 211-214.

Bai, N. R., Banu, N .R. L., Prakash, J. W., Goldi, S. J., 2008. Effect of seaweed extracts (SLF) on the growth and yield of Phaseolus aureus L. Indian Hydrobiol. 11, 113-119.

Dhargalkar, V. K., Pereira, N., 2005. Seaweed: promising plant of the millennium. Sci. Cult. 71, 60-66.

Dwivedi, S. K., Pal, A., Meshram, M. R., 2014. Effect of seaweed saps on soil health and productivity of potato (Solanum tuberosum L.). Curr. Adv. Agric. Sci. 6(2), 133 137.

Dwivedi, S. K., Meshram, M. R., Pal, A., Pandey, N., Ghosh, A., 2014. Impact of natural organic fertilizer (seaweed saps) on productivity and nutrient status of blackgram (Phaseolus mungo L.). Bioscan. 9(4), 1535-1539.

Ferreira, M. I., Lourens, A. F., 2002. The efficacy of liquid seaweed extract on the yield of Canola plants. S. Afr. J. Plant Soil. 19, 159-161.

Galbiattia, J. A., CavalcanteaI, H. L., Ribeiroa, A. G., Pissarraa, T. C. T., 2007. Nitate and sodium contents on lettuce and drained water as function of fertilizing and irrigation water quality in Brazil. Int. J. Plant Prod. 1, 205-214. 
Ganesh, R. J., Chaudhary, D. R., Khadse, V. A., Zodape, S. T., 2015. Utilisation of seaweeds in enhancing productivity and quality of blackgram [Vigna mungo (L.) Hepper] for sustainable agriculture. Indian. J. Nat. Prod. Resour. 6(1), 16-22.

Gurusaravanan, P., Pandiyarajan, V., Jayabalan, N., 2011. Effect of the seaweed liquid fertilizer to enhance the productivity of Vigna radiata (L.) Wiliczek. Green Farm. 2(4), 459-461.

Kumar, G., Sahoo, D., 2011. Effect of seaweed liquid extract on growth and yield of Triticm aestivun var. Pusa gold. J. Appl. Phycol. 23: 251-255.

Pramanick, B., Brahmachari, K., Ghosh, A., 2013. Effect of seaweed saps on growth and yield improvement of green gram. Afr. J. Agric. Res. 8(13), 1180-1186.

Sridhar, S., Rengasamy, R., 2010. Effect of seaweed liquid fertilizers on the growth, biochemical constituents and yield of Tagetes erecta, under field trial. J. Phytol. 2(6), 61-68.

Thirumaran, G., Arumugam, M., Arumugam, R., Anantharaman, P., 2009. Effect of seaweed liquid fertilizer on growth and pigment concentration of Abelmoschus esculentus (L.) Medikus. Am. Euras. J. Agron. 2(2), 57-66.
Turan, M., Köse, C., 2004. Seaweed extracts improve copper uptake of grapevine. Acta Agric. Scand. B. Soil Plant Sci. 54, 213-220.

Venkata Rao, P., Reddy, A. S., Koteswara Rao, Y., 2015. Effect of seaweed liquid fertilizers on productivity of Vigna radiata (L). Wiliczek. Int. J. Res. Chem. Environ. 5(4), 91-94.

Verkleij, F. N., 1992. Seaweed extracts in agriculture and horticulture: a review. Biol. Agric. Hort. 8, 309-324.

Zhang, X., Ervin, E. H., Schmidt, E. R., 2003. Plant growth regulators can enhance the recovery of Kentucky bluegrass sod from heat injury. Crop Sci. 43, 952-956.

Zodape, S. T., 2001. Seaweeds as a biofertilizer. J. Sci. Ind. Res. 60, 378-382.

Zodape, S. T., Kawarkhe, V. J., Patolia, J. S., Warade, A. D., 2008. Effect of liquid seaweed fertilizer on yield and quality of okra (Abelmoschus esculentus L.). J. Sci. Ind. Res. 67(12), 1115-1117.

Zodape, S. T., Soumita, M., Eswaran, K., Reddy, M. P., Chikara, J., 2010. Enhanced yield and nutritional quality in greengram (Phaseolus radiata L.) treated with seaweed (Kappaphycus alvarezii) extract. J. Sci. Ind. Res. 69(6), 468-471.

\section{How to cite this article:}

Reddy, A. S., Venkata Rao, P., Sateesh Babu, J., Ramana, M. V., 2016. Impact of seaweed liquid fertilizers on productivity of blackgram [Vigna mungo (L.) Hepper]. Int. J. Curr. Res. Biosci. Plant Biol. 3(8), 88-92. doi: http://dx.doi.org/10.20546/ijcrbp.2016.308.014 